University of Nebraska - Lincoln

DigitalCommons@University of Nebraska - Lincoln

1971

\title{
Sex Attractant Pheromone of the House Fly: Isolation, Identification and Synthesis
}

D. A. Carlson

USDA

M. S. Mayer

USDA

D. L. Silhacek

USDA

J. D. James

USDA

Morton Beroza

USDA

See next page for additional authors

Follow this and additional works at: https://digitalcommons.unl.edu/entomologyother

Part of the Entomology Commons

Carlson, D. A.; Mayer, M. S.; Silhacek, D. L.; James, J. D.; Beroza, Morton; and Bierl, B. A., "Sex Attractant Pheromone of the House Fly: Isolation, Identification and Synthesis" (1971). Entomology Papers from Other Sources. 11.

https://digitalcommons.unl.edu/entomologyother/11

This Article is brought to you for free and open access by the Entomology Collections, Miscellaneous at DigitalCommons@University of Nebraska - Lincoln. It has been accepted for inclusion in Entomology Papers from Other Sources by an authorized administrator of DigitalCommons@University of Nebraska - Lincoln. 


\section{Authors}

D. A. Carlson, M. S. Mayer, D. L. Silhacek, J. D. James, Morton Beroza, and B. A. Bierl 
Science, New Series, Vol. 174, No. 4004 (Oct. 1, 1971), pp. 76-78

Published by American Association for the Advancement of Science

This article is a U.S. government work, and is not subject to copyright in the United States.

\section{Sex Attractant Pheromone of the House Fly:}

\section{Isolation, Identification and Synthesis}

Abstract. A sex pheromone isolated from the cuticle and feces of the female house fly attracts the male fly; it has been identified as (Z)-9-tricosene. Chemical and biological comparisons of the natural and synthesized compounds show that they are identical.

We report the first isolation, identification, and synthesis of a sex attractant pheromone of the common house fly, Musca domestica L. The compound, for which the name muscalure is proposed, is (Z)-9-tricosene.

The house fly is a danger to the health of man and animals principally because it breeds in manure, garbage, and fermenting crops and carries and spreads typhoid, dysentery, diarrhea, cholera, yaws, trachoma, and many other diseases (1). It also serves as an intermediate host of roundworms and tapeworms. The mating behavior of
(4). Other studies revealed that male flies were also attracted to fly feces and lipid extracts of fly feces (5), and cuticular lipids (6).

Fractionation of cuticular and fecal lipids disclosed that the attractant, a hydrocarbon, was produced by only sexually mature females (7) for the attraction of only sexually mature males (6). Accordingly, the attractant was obtained from sexually mature, laboratory-reared female house flies (Orlando Regular strain) by surface washing to remove the cuticular lipids with hexane or ether. The concentrate was chromatographed on a silicic acid column, and the active fraction was eluted with hexane; elution with more polar solvents has yielded no active material (7). Thin-layer chromatography (TLC) of the active percolate on silica gelsilver nitrate plates (8) with 1 percent ethyl ether in hexane gave four zones. Chromatographic mobility of the zone with most of the activity $\left(R_{F}, 0.70\right)$ was consistent with that of a long-chain monoolefin; $R_{F}$ values of the other zones were consistent with paraffins $\left(R_{F}\right.$ $0.95)$ and polyolefins $\left(R_{F} 0.25,0.10\right)$. Larger amounts of the monoolefin fraction were obtained by column chromatography (9), and gas chromatography (GC) of this fraction (10) gave peaks corresponding to 22 percent $\mathrm{C}_{23},<1$ percent $C_{25}, 65$ percent $C_{27}, 10$ percent $C_{29}$, and 3 percent $C_{31}$. Materials from the three major peaks were collected by preparative GC (11), and the $\mathrm{C}_{23}$ material was by far the most attractive. It gave a single peak on poly(diethylene glycol succinate) (DEGS), OV-17, and SE-30 columns (10) with retention times [Kovats indices (12)] that suggested a straight-chain monoolefin. Its mass spectrum showed a molecular ion at $m / e 322$ corresponding to $\mathrm{C}_{23} \mathrm{H}_{46}$. Its activity was lost, and its GC peak disappeared on treatment with 5 percent bromine in carbon tetrachloride, verifying the presence of a double bond. Position of the double bond was determined by microozonolysis of a $10-\mu \mathrm{g}$ sample followed by GC of the products (13); retention times of the peaks coincided with those of nonanal and tetradecanal. Configuration of the double bond was established as $(Z)$ by TLC on silica gel-silver nitrate plates (14). Absence of branching was confirmed by instantaneous hydrogenation (15) of $100 \mu \mathrm{g}$ of the olefin followed by combined GC-mass spectrometry of the saturated product (16); the mass spectrum matched that of $n$-tricosane.

The data indicated that the sex at- 
tractant was (Z)-9-tricosene (17). It was prepared by a Wittig synthesis as follows. 1-Bromotetradecane and triphenylphosphine were refluxed overnight in acetonitrile; the resulting salt (82 percent yield) was dissolved in dry dimethyl sulfoxide. $n$-Butyllithium and then nonanal were added. The product of this reaction was chromatographed on a silica gel column with hexane, yielding 9-tricosene (73 percent from the salt; $n_{\mathrm{D}}{ }^{26}=1.4517 ;$ b.p. $157^{\circ}$ to $158^{\circ} \mathrm{C}$ at $0.1 \mathrm{~mm}-\mathrm{Hg}$ ) which was 93.4 percent pure by GC. Thin-layer chromatography of the product (18) showed that 85 percent of the $(Z)$ isomer and 15 percent of the $(E)$ isomer were present; the isomers were separated on a silver nitrate-silica gel column with hexane (9). The $(Z)$ isomer had a nuclear magnetic resonance spectrum consistent with 9-tricosene (19): $\left(\mathrm{CDCl}_{3}, \tau\right)$ two methyl groups as a triplet at 9.12; $17 \mathrm{CH}_{2}$ groups at 8.73; two $\mathrm{CH}_{2}$ groups adjacent to the double bond as a multiplet at $8.01 ; \mathrm{CH}=\mathrm{CH}$ as a triplet at 4.72. The natural olefin had the same $R_{F}$ value as the $(Z)$ isomer $(14$, 18 ), and the infrared spectra (20) of the two were identical, with no band at $967 \mathrm{~cm}^{-1}[(E)$ unsaturation]. Further confirmation of identity was obtained by instantaneously hydrogenating both materials in the GC pathway (15) to saturated compounds; the products had the same retention time as authentic $n$-tricosane (21). A sample of $\mathrm{C}_{23}$ olefin isolated from fly feces was indistinguishable from the cuticular $\mathrm{C}_{23}$ olefin by infrared spectra, attractant studies, and retention time on two different columns (22).

Bioassays were conducted in a laboratory olfactometer as described (6, 7). The olfactometer contained 300 virgin male house flies (23) in a Plexiglas cage ( 90 by 45 by $54 \mathrm{~cm}$ ) to which filtered, humidified outside air was delivered; the air was passed through two ports in the front face of the cage and exited through a screen that formed the rear face of the cage. Each port was a horizontal glass cylinder $(8.0 \mathrm{~cm}$, inside diameter, by $40 \mathrm{~cm}$ ) with a vertical screen at its midpoint and an inverted screen funnel at its inner end. Each test material was applied as a hexane solution to filter paper and positioned in the outer end of one of the cylinders; an internal standard, Edamin (24), was similarly positioned in the other cylinder. Incoming air passed over the sample (or standard) and through the cylinder and cage of flies in this order before exiting. Re-

Table 1. House flies attracted to natural and synthetic materials in 30 -minute tests, 300 male flies per test.

\begin{tabular}{|c|c|c|c|c|c|c|}
\hline \multirow{2}{*}{ Material tested } & \multirow{2}{*}{\multicolumn{2}{|c|}{ Amount }} & \multirow{2}{*}{$\begin{array}{l}\text { Tests } \\
\text { (No.) }\end{array}$} & \multicolumn{2}{|c|}{$\begin{array}{l}\text { Percentage of flies } \\
\text { attracted to }\end{array}$} & \multirow{2}{*}{$\begin{array}{l}\text { Activity } \\
\text { quotient } \dagger\end{array}$} \\
\hline & & & & $\begin{array}{c}\text { Test } \\
\text { material }\end{array}$ & $\begin{array}{l}\text { Internal } \\
\text { standard * }\end{array}$ & \\
\hline \multicolumn{7}{|c|}{ Natural } \\
\hline Fecal lipid $\$$ & & $\mathrm{mg}$ & 205 & 16.9 & 6.9 & \\
\hline Cuticular lipid & & $\mathrm{mg}$ & 5 & 22.8 & 5.1 & +2.2 \\
\hline Cuticular hydrocarbons & & $\mathrm{mg}$ & 6 & 18.4 & 7.3 & +1.2 \\
\hline Cuticular paraffins & & $\S$ & 5 & 4.6 & 7.9 & -0.5 \\
\hline Cuticular monoolefins & & $\S$ & 10 & 19.6 & 12.7 & +1.5 \\
\hline Cuticular polyolefins & & $\S$ & 6 & 16.2 & 13.9 & +0.2 \\
\hline Cuticular monoolefin $\mathbf{C}_{23}$ & 100 & $\mu \mathrm{g}$ & 6 & 23.0 & 4.5 & +1.6 \\
\hline Cuticular monoolefin $\mathrm{C}_{\mathrm{g} \pi}^{-1}$ & 50 & $\mu \mathrm{g}$ & 15 & 6.7 & 7.0 & -0.1 \\
\hline Cuticular monoolefin $\mathbf{C}_{29}$ & 150 & $\mu \mathrm{g}$ & 5 & 5.6 & 4.3 & +0.1 \\
\hline \multicolumn{7}{|c|}{ Synthetic } \\
\hline (2) & 50 & $\begin{array}{l}\mu \mathrm{g} \\
\mu \mathrm{g}\end{array}$ & 30 & 18.9 & $\begin{array}{l}.0 .5 \\
6.2\end{array}$ & $\begin{array}{l}+0.3 \\
+1.8\end{array}$ \\
\hline \multirow{5}{*}{ (E)-9-Tricosene } & 100 & $\mu \mathrm{g}$ & 15 & 26.9 & 18.3 & +2.1 \\
\hline & 250 & $\mu \mathrm{g}$ & 5 & 26.1 & 5.8 & +1.5 \\
\hline & 10 & $\mu \mathrm{g}$ & 5 & 9.4 & 6.8 & +0.2 \\
\hline & 100 & $\mu \mathrm{g}$ & 7 & 9.6 & 5.2 & +0.4 \\
\hline & 200 & $\mu \mathrm{g}$ & 5 & 11.7 & 6.9 & +0.4 \\
\hline
\end{tabular}

* One gram of Edamin (24). †[(No. of flies attracted to test material - No. attracted to Eda$\mathrm{min}) / \mathrm{No}$. of flies in olfactometer] $\div$ [(No. of flies attracted to external standard - No. attracted io Edamin)/No. of flies in olfactometer] (6). ‡External standard. $\$$ Amount found in $500 \mathrm{mg}$ of cuticular hydrocarbon.

sponding flies that penetrated the funnel to reach the attractant were trapped and counted. Sixty milligrams of fecal lipid (5) served as an external standard. Each group of 300 newly emerged male flies (less than 3 hours old) was added to the olfactometer under $\mathrm{CO}_{2}$ narcosis and held 24 hours before testing. Thirty-minute tests with intervening 30minute recovery periods were then conducted over a 2-day period.

The activity of the natural materials can be ascribed to the $\mathrm{C}_{23}$ monoolefin subsequently identified as (Z)-9-tricosene (Table 1). A 50- $\mu \mathrm{g}$ sample of the synthetic $(Z)$ isomer attracted more flies than $200 \mu \mathrm{g}$ of the $(E)$ isomer or 60 $\mathrm{mg}$ of crude fecal lipid. The other cuticular monoolefins $\left(\mathrm{C}_{27}\right.$ and $\left.\mathrm{C}_{29}\right)$ and polyolefins were weakly active. The following bioassays, not included in Table 1, were also performed. Addition of 50 to $100 \mu \mathrm{g}$ of muscalure to an inactive portion of 100 or $1000 \mu \mathrm{g}$ of either the cuticular paraffins or $n$-octacosane produced slightly enhanced activity over that of the muscalure alone; at no time was masking (reduction in activity) noted. No masking was observed when $(Z)$ and $(E)$ isomers were mixed at ratios up to $1: 3$, respectively. In tests of longer duration, $5 \mu \mathrm{g}$ of muscalure and Edamin were each applied to glass plates; respective captures were 61 and 14 percent in 60 minutes and 76 and 15 percent in 90 minutes.

In addition, male flies apparently became sexually stimulated on exposure to the synthetic or natural pheromone, since the observed number of mating attempts increased markedly near a treated filter paper inserted directly into the olfactometer.

In limited field trials, about twice as many flies landed on a grid treated with $100 \mu \mathrm{g}$ of muscalure as on an untreated grid. Though not a potent attractant as compared to some sex pheromones, muscalure is expected to be inexpensive to manufacture and it may have good potential for reducing the amount of insecticide needed to control the ubiquitous house fly.

Entomology Research Division, D. A. CARLSON M. S. MAYER USDA Agricultural Research Service, Gainesville, Florida 32601

D. L. SilhaceK

Market Quality Research Division, USDA Agricultural Research Service, Gainesville

J. D. JAMES

Entomology Research Division, USDA Agricultural Research Service, Gainesville

Entomology Research Division, Morton Beroza B. A. BIERL USDA Agricultural Research Service, Beltsville, Maryland 20705

References and Notes

1. The House Fly: How to Control It, USDA Leaflet No. 390 (U.S. Department of Agriculture, Washington, D.C., 1969), p. 2.

2. A. Berlese, Riv. Patol. Veg. 9, 345 (1902); G. C. Hewitt, Quart. J. Microscop. Sci. 25, 495 (1908); R. H. Hutchinson, Bull. U.S. Dept. Agr. 345, 1 (1916); E. B. Basden, Bull. Entomol. Res. 37, 381 (1947); G. W. Barber and E. B. Starnes, J. N.Y. Entomol. Soc. 57, 203 (1949); C. M. Murvosh, G. C. LaBrecque, C. N. Smith, Ohio J. Sci. 65(2), 68 (1965).

3. Aristotle, History of Animals, I. Bekker, Ed. 
(Royal Prussian Academy of Science, Berlin, 1831), book 5, chap. 8, pp. 542, A6-10.

4. W. M. Rogoff, A. D. Beltz, J. O. Johnsen, F. W. Plapp, J. Insect. Physiol. 10, 239 (1964).

5. M. S. Mayer and C. W. Thaggard, ibid. 12, 891 (1966); M. S. Mayer and J. D. James, ibid. 17, 833 (1971)

6. D. L. Silhacek, M. S. Mayer, D. A. Carlson, J. D. James, ibid., in press.

7. D. L. Silhacek, D. A. Carlson, M. S. Mayer, J. D. James, ibid., in press.

8. Silica gel $G$ containing 25 percent silver nitrate (Uniplates from Analtech, Inc., Newark, Del.).

9. With a column of Adsorbosil-CABN, 100/140 mesh, 25 percent silver nitrate on silica gel (Applied Science Laboratories, State College, $\mathrm{Pa}$.), paraffins, monoolefins, and polyolefins Pa.), paraffins, monoolefins, and polyolefins
were eluted with 0,1 , and 10 percent ether in hexane, respectively.

10. F \& M Model 810 instrument with a flame ionization detector was equipped with stainless steel columns; 5 percent DEGS on $60 / 80$ Chromosorb G-DMCS $(1.8 \mathrm{~m}$ by $4 \mathrm{~mm}$ i.d.); 3 percent OV-17 on 100/120 Gas Chrom $Q$ ( $2 \mathrm{~m}$ by $4 \mathrm{~mm}$ i.d.); 5 percent SE-30 on $100 / 120$ Varaport 30 (1.8 $\mathrm{m}$ by $4 \mathrm{~mm}$ i.d.).

11. Varian Model 90-P instrument, equipped with thermal conductivity detector and the 5 percent SE-30 column (10), was temperature programmed from $150^{\circ}$ to $280^{\circ} \mathrm{C}$.
prome

12. E. Kovats, Advan. Chromatogr. 1, 229 (1966)

13. M. Beroza and B. A. Bierl, Anal. Chem. 39, 1311 (1967).
14. Samples of (Z)- and (E)-9-octadecene gave spots at $R_{F}, 0.70$ and 0.90 , respectively, on TLC plates (8) developed three times with hexane. The natural olefin gave a spot at 0.70 .

15. M. Beroza and R. Sarmiento, Anal. Chem. 38, 1042 (1966).

16. Finnigan Model 1015 mass spectrometer interfaced with a Gohlke glass separator to Varian GC equipped with 3 percent OV-101 on $80 / 100 \mathrm{Gas}$ Chrom $Q$ (glass column, $2 \mathrm{~m}$ by $4 \mathrm{~mm}$ i.d.).

17. (Z)-9-Tricosene has been reported as one of the major cuticular hydrocarbons of several cockroach species [L. L. Jackson, Lipids 5 38 (1970)].

18. Spots at $R_{F}, 0.70$ and 0.90 , obtained as described (14), for the $(Z)$ and $(E)$ isomers, respectively, were eluted and quantified by respecti

19. Determined with a Varian $\mathrm{XL} 100$ instrument We thank K. Scott of the Department of Chemistry, University of Florida, Gainesville, for determining the spectrum.

20. Perkin-Elmer Model 237 instrument, liquid film on $\mathrm{NaCl}$ plates.

21. This and other authentic straight-chain hydrocarbons were obtained from Analabs, Inc., North Haven, Conn.

22. DEGS and SE-30 columns (10).

23. From a laboratory colony of house flies resistant to phosphate insecticides (Cradson-P).

24. Hydrolyzed milk protein, Sheffield Chemical Co., Union, N.J.

27 August 1971 